\title{
'Jurema-de-embira' seed germination under water stress and at different temperatures
}

\author{
Narjara W. Nogueira ${ }^{1}$, Salvador B. Torres ${ }^{1}$, Rômulo M. O. de Freitas ${ }^{2}$, \\ Thiago H. da S. Castro ${ }^{1} \&$ Francisco V. da S. Sá \\ ${ }^{1}$ Universidade Federal Rural do Semi-Árido/Centro de Ciências Agrárias. Mossoró, RN. E-mail: narjara.nogueira@ufersa.edu.br; sbtorres@ufersa.edu.br \\ (Corresponding author); thiago.castro.93@hotmail.com \\ ${ }^{2}$ Instituto Federal de Educação, Ciência e Tecnologia Baiano/Campus Valença. Valença, BA. E-mail: romulomagno_23@hotmail.com \\ ${ }^{3}$ Universidade Federal de Campina Grande/Centro de Tecnologia e Recursos Naturais/Unidade Acadêmica de Engenharia Agrícola. Campina Grande, \\ PB. E-mail: vanies_agronomia@hotmail.com
}

\section{Key words:}

Mimosa ophthalmocentra Mart. ex

Benth

Fabaceae

forest species

Caatinga

osmotic potentials

\section{A B S T R A C T}

The process of water imbibition by the seed depends on temperature and water availability, which according to the absorbed water retention capacity will determine the success of the germination process. Thus, this study aimed to investigate the effects of water stress on the germination and vigor of 'jurema-de-embira' seeds under different temperatures. The experimental design was completely randomized in a $7 \times 4$ factorial scheme (osmotic potential and temperature) with four replicates of 25 seeds each. The osmotic potentials of 0 , $-0.1,-0.2,-0.3,-0.4,-0.5$ and $-0.6 \mathrm{MPa}$ at temperatures of 25,30 and $35^{\circ} \mathrm{C}$ and alternated of $20-30{ }^{\circ} \mathrm{C}$, under photoperiod of $8 \mathrm{~h}$, were evaluated. Germination percentage, germination speed index, shoot and root length, shoot dry biomass, root dry biomass and total biomass were evaluated. Water stress negatively affected the germination and vigor of 'jurema-deembira' seedlings from the potential of $-0.2 \mathrm{MPa}$ on, whose effects are more evident at the temperature of $35^{\circ} \mathrm{C}$. The alternated temperature of $20-30{ }^{\circ} \mathrm{C}$ allowed greater tolerance to water stress for the germination of 'jurema-de-embira' seeds.

\section{Palavras-chave:}

Mimosa ophthalmocentra Mart. ex

Benth

Fabaceae

espécie florestal

Caatinga

potenciais osmóticos

\section{Germinação de sementes de jurema-de-embira sob estresse hídrico e em diferentes temperaturas}

\begin{abstract}
R E S U M O
O processo de embebição de água pelas sementes é dependente da temperatura e da sua disponibilidade que, de acordo com a capacidade de retenção da água absorvida, determinará o sucesso do processo de germinação. Desta forma, objetivou-se verificar os efeitos do estresse hídrico na germinação e no vigor de sementes de jurema-de-embira, em diferentes temperaturas. O delineamento experimental foi inteiramente casualizado, em esquema fatorial $7 \times 4$ (potencias osmóticos e temperaturas) com quatro repetições de 25 sementes cada uma. Foram avaliados os potenciais osmóticos de $0 ;-0,1 ;-0,2 ;-0,3$; $-0,4 ;-0,5$ e $-0,6 \mathrm{MPa}$ nas temperaturas de 25,30 e $35^{\circ} \mathrm{C}$ e alternadas de $20-30{ }^{\circ} \mathrm{C}$, sob fotoperíodo de $8 \mathrm{~h}$. Avaliaram-se a porcentagem e o índice de velocidade de germinação, comprimento da parte aérea e da raiz, massa seca da parte aérea, da raiz e total. O estresse hídrico afetou negativamente a germinação e o vigor das plântulas de jurema-de-embira a partir do potencial de $-0,2 \mathrm{Mpa}$, cujos efeitos são mais evidentes na temperatura de $35^{\circ} \mathrm{C}$. A temperatura alternada de $20-30^{\circ} \mathrm{C}$ permitiu maior tolerância ao estresse hídrico para a germinação de sementes de jurema-de-embira.
\end{abstract}




\section{INTRODUCTION}

Mimosa ophthalmocentra Mart. ex Benth. is a species native to the Caatinga biome, popularly known as 'juremade-embira' (Cavalcanti et al., 2009). Its occurrence is also commonly recorded in areas of riparian forest (Lacerda et al., 2007) and regeneration (Sampaio et al., 2010), being a species with multiple uses, with high energetic and timber potential (Figueirôa et al., 2005).

The information on the techniques of propagation of arboreal species of the Caatinga is still considered as scarce. Therefore, it becomes important to know the factors that limit the development of the species, particularly water deficit, a common situation in the semi-arid region, where the Caatinga biome is inserted.

Water is one of the most important factors that affect germination, because it reactivates the metabolism and is involved in all other steps of germination (Marcos-Filho, 2015). Very negative osmotic potentials can delay or reduce germination. Hence, there is the need for a minimum level of water availability for the seed to germinate, which will depend on its chemical composition and permeability of the tegument (Verslues et al., 2006). Thus, it is significant the presence of an adequate level of hydration that allows the reactivation of the metabolic processes, culminating in the growth of the embryo axis (Marcos-Filho, 2015).

In this context, some studies have been conducted using solutions with different osmotic potentials to moisten the substrate, such as Jeller et al. (2003), with Cassia excelsa Schrad.; Ferraz-Grande \& Takaki (2006), with seeds of Caesalpinia peltophoroides Benth.; Stefanello et al. (2006), with seeds of Foeniculum vulgare Miller. and Pelegrini et al. (2013), with seeds of Erythrina falcata Benth.

Therefore, this study aimed to evaluate the effects of water stress on the germination and vigor of 'jurema-de-embira' seeds at different temperatures.

\section{Material ANd Methods}

The 'jurema-de-embira' seeds were obtained in 2014 through the collection of ripe fruits (pods) from 25 matrices located in the municipality of Mossoró - RN ( $5^{\circ} 11^{\prime} 15^{\prime \prime} \mathrm{S}, 37^{\circ}$ $20^{\prime} 39^{\prime \prime} \mathrm{W}$ and altitude of $16 \mathrm{~m}$ ). After collecting the fruits, the seeds were manually removed, cleaned, purged, placed in tin cans and maintained in cold and dry chamber $\left(15^{\circ} \mathrm{C}\right.$ and $50 \%$ $\mathrm{RH}$ of the environment) until their utilization.

The statistical design was completely randomized, in $4 \mathrm{x} 7$ factorial scheme (temperatures $\mathrm{x}$ osmotic potentials) and each treatment was composed of 4 replicates of 25 seeds.

For exhibiting tegument dormancy, the tips of the seeds were cut with scissors on the opposite end of the hilum. Then, they were planted on Germitest paper towel, hydrated with PEG 6000 solution, using a volume of 2.5 times the dry weight of the paper, produced according to the tabulated values proposed by Villela et al. (1991) to simulate the osmotic levels of $0,-0.1$, $-0.2,-0.3,-0.4,-0.5$ and $-0.6 \mathrm{MPa}$.

The germination tests were conducted in Biochemical Oxygen Demand (B.O.D.) germinators, regulated at the temperatures of $25,30,35^{\circ} \mathrm{C}$ and alternated of $20-30{ }^{\circ} \mathrm{C}$, with photoperiod of $8 \mathrm{~h}$ of light. Daily counts were made until the $7^{\text {th }}$ day after sowing, considering as germinated the seeds that formed normal seedlings (Brasil, 2009).

The analyzed variables were: a) germination percentage expressed in percentage of normal seedlings; b) germination speed index - simultaneously conducted with the germination test, in which the seedlings were daily evaluated until the $7^{\text {th }}$ day after sowing, and calculated according to the equation proposed by Maguire (1962); c) shoot and root length - at the end of the germination test, the root length (base of collar to root tip) and shoot length (base of collar to the tip of the apical meristem) of all normal seedlings of the experimental unit were measured using a ruler graduated in centimeters; d) shoot, root and total dry matter of the seedlings - all normal seedlings of the experimental unit were divided into roots and shoots and dried in a forced-air oven at $65^{\circ} \mathrm{C}$ until constant weight $(48$ $\mathrm{h})$, being subsequently weighed on a precision analytical scale $(0.01 \mathrm{~g})$, with values expressed in $\mathrm{mg}$ plant $^{-1}$. Total dry matter was determined by the sum of shoot and root dry matter.

The results were subjected to analysis of variance by F test, at 0.05 probability level using the statistical program Sisvar (Ferreira, 2011). In case of significance, the data were subjected to regression analysis using the program SigmaPlot. The model was selected considering the biological explanation and significance of the mean square of the regression.

\section{Results AND Discussion}

The water stress affected the formation of normal seedlings of 'jurema-de-embira' from the potential of -0.1 $\mathrm{MPa}$ on at temperature of $35^{\circ} \mathrm{C}$. For the other temperatures, the negative effects of the water stress were observed from the potential of $-0.2 \mathrm{MPa}$ on, with germination percentages lower than $20 \%$ of normal seedlings at the potential of -0.4 $\mathrm{MPa}$ (Figure 1A).

The reduction of germination due to the increase in water deficit was also observed by Miranda et al. (2014) in seeds of Prosopis juliflora (Sw.) D.C. These authors reported that, at the highest temperatures $\left(35\right.$ and $\left.40^{\circ} \mathrm{C}\right)$, the reduction was faster than at the lowest temperatures $\left(25\right.$ and $\left.30^{\circ} \mathrm{C}\right)$.

The highest GSI was recorded at the temperature of $35^{\circ} \mathrm{C}$ and water potential of $0 \mathrm{MPa}$ (Figure 1B), which occurred because higher temperatures increased the speed of the metabolic processes, shortening the duration of the phase II of the imbibition process. According to Nascimento (2005), very low or very high temperatures can alter both the speed and final percentage of germination. Generally, low temperatures reduce the germination speed, while high temperatures increase it.

At all temperatures, there was a reduction in germination speed from -0.1 $\mathrm{MPa}$ on and the temperature of $35^{\circ} \mathrm{C}$ led to the highest reductions. On the other hand, the alternated temperatures of $20-30{ }^{\circ} \mathrm{C}$ caused lower reductions in germination speed until the osmotic potential of - $0.5 \mathrm{MPa}$.

Seeds of C. peltophoroides suffered reductions in GSI under water stress, but without significant differences from -0.2 to -0.4 MPa (Ferraz-Grande \& Takaki, 2006). In C. excelsa, there was tolerance until $-0.8 \mathrm{MPa}$, with significant reduction from $-0.6 \mathrm{MPa}$ on at $27^{\circ} \mathrm{C}$ (Jeller et al., 2003). For F. vulgare seeds, 

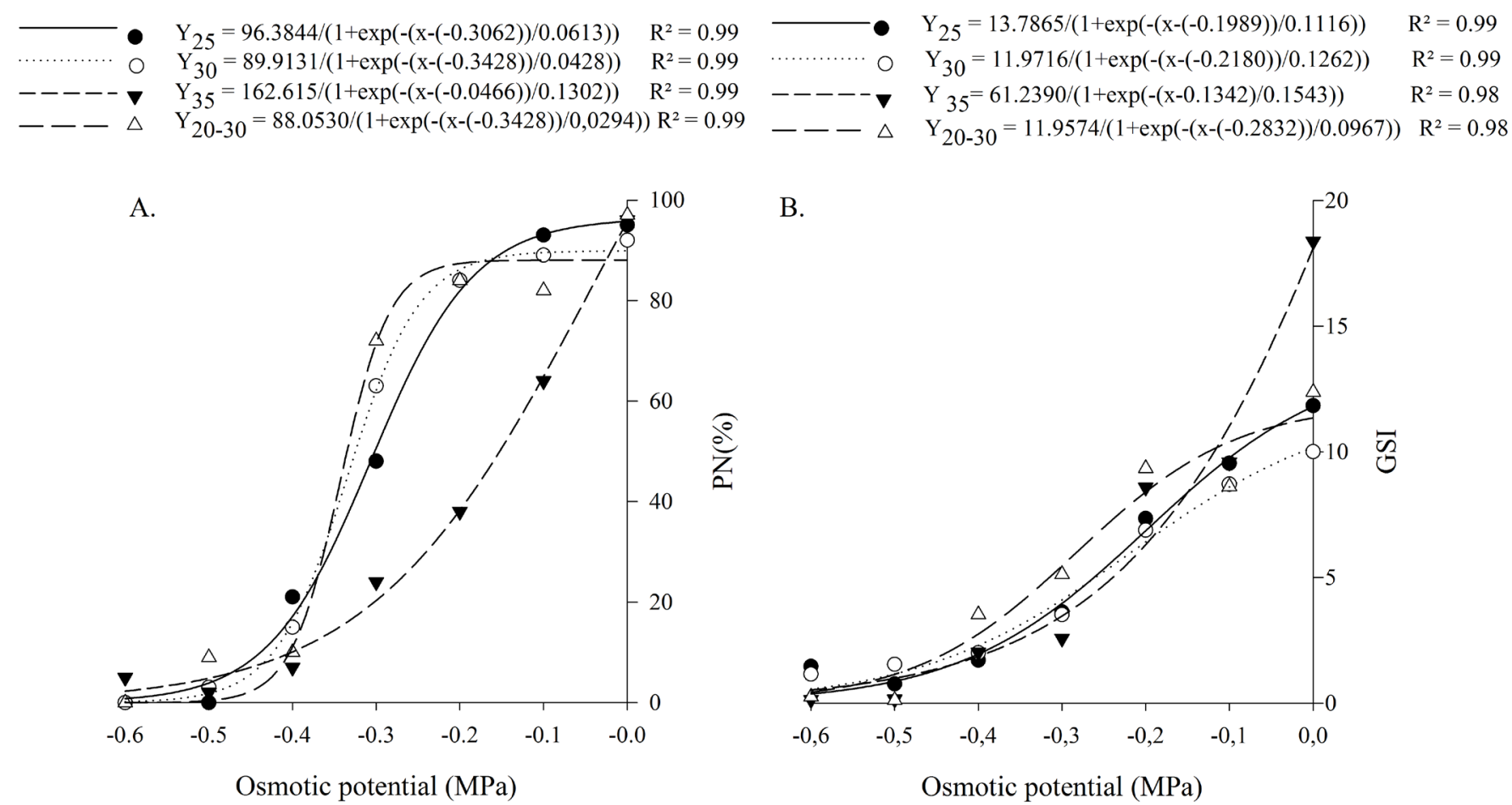

Osmotic potential (MPa)

Figure 1. Percentage of normal seedlings - PN (A) and germination speed index - GSI (B) of 'jurema-de-embira' (Mimosa ophthalmocentra Mart. ex Benth.), subjected to water stress at different temperatures

there was a linear reduction of germination and speed, reaching zero at -0.3 MPa (Stefanello et al., 2006). In E. falcata seeds, the reduction in water availability to potentials lower than -0.4 MPa drastically inhibited the germination percentage and speed (Pelegrini et al., 2013).

In seeds of Bulnesia retama (Gill. ex. Hook.), Rivera et al. (2007) observed that, at lower values of water availability, the germination speed was affected by low and high temperatures $\left(18\right.$ and $32^{\circ} \mathrm{C}$, respectively), and the lowest reduction due to the decrease in water availability occurred at intermediate temperatures $\left(25^{\circ} \mathrm{C}\right)$.

Shoot length was affected at all temperatures, from the water availability of $-0.1 \mathrm{MPa}$ on, except for the temperature of $30{ }^{\circ} \mathrm{C}$, at which the reduction only occurred from -0.2 $\mathrm{MPa}$ on. As observed for the GSI, seedlings subjected to the temperatures of 35 and $20-30{ }^{\circ} \mathrm{C}$, suffered the highest and lowest reductions of shoot length, respectively (Figure 2A).

Regardless of temperature, with the increase in water deficit, the 'jurema-de-embira' starts to invest in the production of roots, whose effect is more evident between the osmotic potentials of -0.2 and $-0.3 \mathrm{MPa}$, especially at the alternated temperatures of $20-30{ }^{\circ} \mathrm{C}$. From this point on, there was a reduction in the root system. At all temperatures, the values of root length are only inferior to those in the condition of full water supply $(0 \mathrm{MPa})$ at potentials below $-0.5 \mathrm{MPa}$ (Figure $2 \mathrm{~B}$ ). $\begin{array}{lcc}- & \mathrm{Y}_{25}=5.3680 /(1+\exp (-(\mathrm{x}-(-0.2167)) / 0.0941)) & \mathrm{R}^{2}=0.99 \\ \circ & \mathrm{Y}_{30}=3.7226 /(1+\exp (-(\mathrm{x}-(-0.2595)) / 0.0751)) & \mathrm{R}^{2}=0.99 \\ \boldsymbol{\nabla} & \mathrm{Y}_{35}=17.3318 /(1+\exp (-(\mathrm{x}-(0.1656)) / 0.1548)) & \mathrm{R}^{2}=0.97 \\ \triangle & \mathrm{Y}_{20-30}=6.9369 /(1+\exp (-(\mathrm{x}-(-0.1003)) / 0.1515)) & \mathrm{R}^{2}=0.97\end{array}$

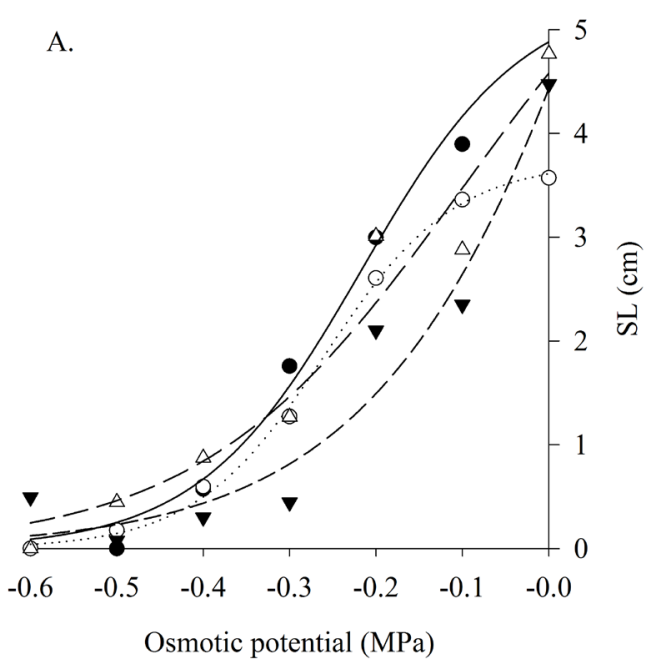

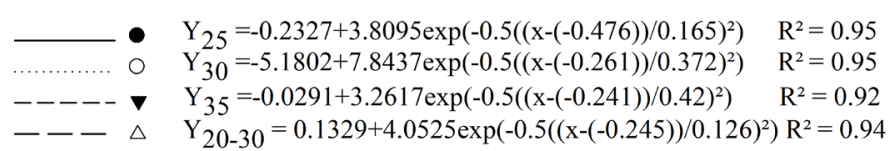

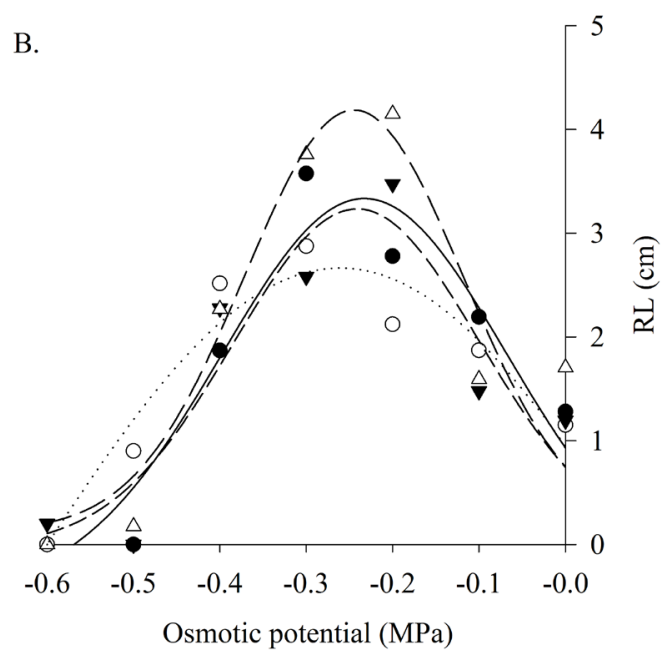

Figure 2. Shoot length - SL (A) and root length - RL (B) of seedlings of 'jurema-de-embira' (Mimosa ophthalmocentra Mart. ex Benth.), subjected to water stress at different temperatures 


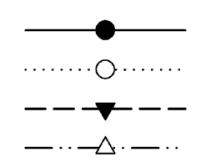

$25{ }^{\circ} \mathrm{C}$ (Observed mean: $3.34 \mathrm{mg}$ ) $30^{\circ} \mathrm{C}$ (Observed mean: $3.65 \mathrm{mg}$ ) $35{ }^{\circ} \mathrm{C}$ (Observed mean: $2.76 \mathrm{mg}$ ) 20-30 ${ }^{\circ} \mathrm{C}$ (Observed mean: $2.18 \mathrm{mg}$ )

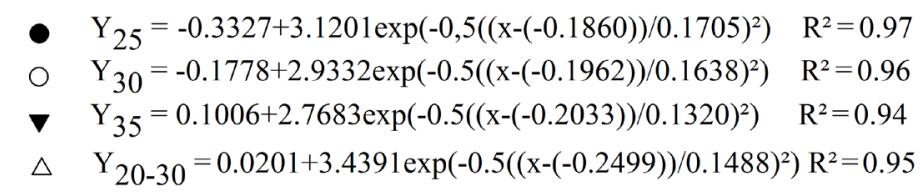

B.

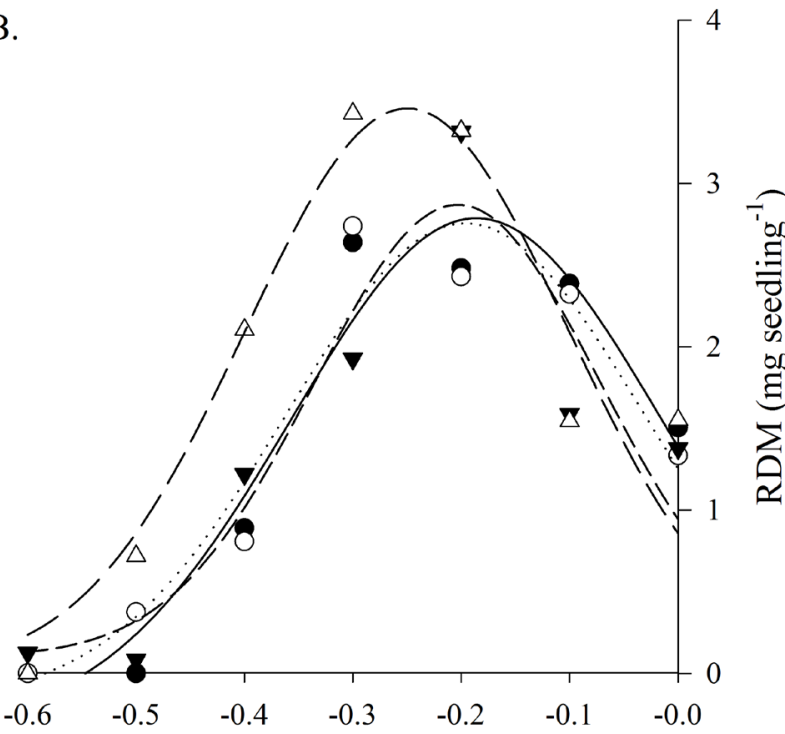

Osmotic potential (MPa)
A.

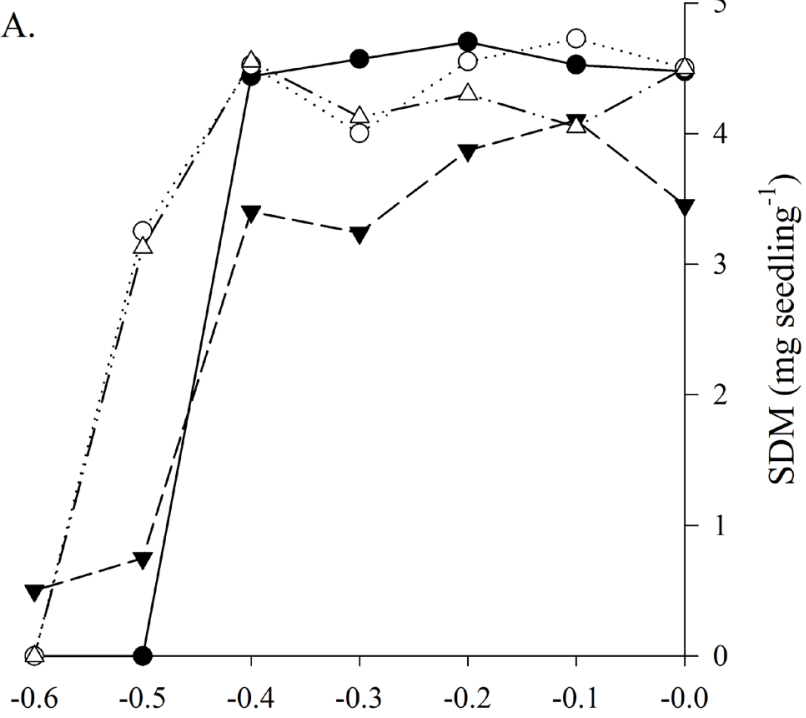

Osmotic potential (MPa)

Figure 3. Shoot dry matter - SDM (A) and root dry matter - RDM (B) of seedlings of 'jurema-de-embira' (Mimosa ophthalmocentra Mart. ex Benth.), subjected to water stress at different temperatures

The increase in root length when plants are subjected to moderate water deficits is due to the need for the root system to be able to absorb water at greater depths (Ávila et al., 2007).

In seedlings of Moringa oleifera L., Rabbani et al. (2012) observed that root and shoot lengths were reduced as the water availability decreased, and root length was more severely affected by the water stress, different from the result observed in the present study. The authors attribute this reduction to the delay in the emergence of the hypocotyl and a lower root growth rate caused by the reduction in cell expansion and, as a consequence, decrease in cell turgor.

Although there were reductions in shoot length from -0.1 $\mathrm{MPa}$ on, the dry matter showed a different behavior, with more evident reductions from $-0.4 \mathrm{MPa}$ on and no fit of the curve (Figure 3A)

In seedlings of M. oleifera, Rabbani et al. (2012) reported increase in the biomass from $-0.1 \mathrm{MPa}$ on and a reduction for the subsequent potentials, which allows to infer about the potential of the water restriction, which can improve the performance of the 'moringa' seeds, acting as osmotic conditioning (Santos et al., 2011).

The behavior of the investment in root dry matter was similar to that of root length, in which, with the increase in water deficit, the species starts to invest in greater accumulation of biomass in the roots, and this effect was more evident between the osmotic potentials of -0.1 and $-0.3 \mathrm{MPa}$. The greater growth of roots occurred under alternated temperatures of $20-30{ }^{\circ} \mathrm{C}$, at which the effects of water deficit were more evident from the potential of $-0.5 \mathrm{MPa}$ on (Figure $3 \mathrm{~B}$ ).

For total dry matter, with the reduction in water availability, there was a slight increase in relation to the control $(0 \mathrm{MPa})$.
The reduction in total dry matter of the seedlings occurred from -0.4 MPa on, and the highest and lowest reductions of biomass were observed at the temperatures of 35 and 20-30 ${ }^{\circ} \mathrm{C}$, respectively (Figure 4 ).

Similarly, Gordin et al. (2015) observed reductions of dry matter in seedlings of Guizotia abyssinica Cass., which followed the trend of reductions in growth, and the effects were more abrupt at $-0.4 \mathrm{MPa}$.

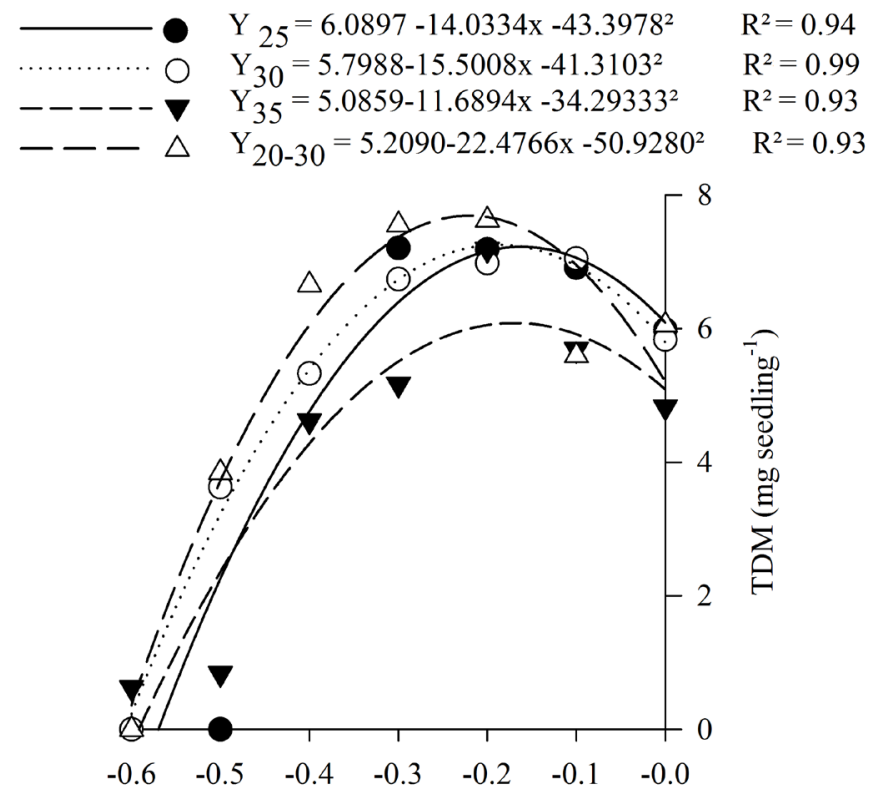

Osmotic potential (MPa)

Figure 4. Total dry matter - TDM of seedlings of 'juremade-embira' (Mimosa ophthalmocentra Mart. ex Benth.), subjected to water stress at different temperatures 


\section{Conclusions}

1. Water stress negatively affects the germination of 'jurema-de-embira' seeds and the initial development of its seedlings from the potential of $-0.2 \mathrm{MPa}$ on, and the effects were more evident at temperature of $35^{\circ} \mathrm{C}$.

2. The alternated temperatures of $20-30{ }^{\circ} \mathrm{C}$ allow higher tolerance to water stress for the germination of 'jurema-deembira' seeds.

\section{Literature Cited}

Ávila, M. R.; Braccini, L. A.; Scapim, C. A.; Fagliari, J. R.; Santos, J. L. Influência do estresse hídrico simulado com manitol na germinação de sementes e crescimento de plântulas de canola. Revista Brasileira de Sementes, v.29, p.98-106, 2007. http://dx.doi. org/10.1590/S0101-31222007000100014

Brasil. Ministério da Agricultura, Pecuária e Abastecimento. Regras para análise de sementes. Brasília: MAPA/ACS, 2009. 399p.

Cavalcanti, A. D. C.; Rodal, M. J. N.; Sampaio, E. V. S. B.; E Costa, K. C. C. Mudanças florísticas e estruturais, após cinco anos, em uma comunidade de Caatinga no Estado de Pernambuco, Brasil. Acta Botânica Brasílica, v.23, p.1210-1212, 2009. http://dx.doi. org/10.1590/S0102-33062009000400032

Ferraz-Grande, F. G. A.; Takaki, M. Efeitos da luz, temperatura e estresse de água na germinação de sementes de Caesalpinia peltophoroides Benth. Caesalpinoideae). Bragantia, v.65, p.3742, 2006. http://dx.doi.org/10.1590/S0006-87052006000100006

Ferreira, D. F. Sisvar: A computer statistical analysis system. Ciência e Agrotecnologia, v.35, p.1039-1042, 2011. http://dx.doi. org/10.1590/S1413-70542011000600001

Figueirôa, J. M.; Pareyn, F. G. C.; Drumond, M.; Araújo, E. L. Madeireiras. In: Sampaio, E. V. S. B (org.). Espécies da flora nordestina de importância econômica potencial. Recife: Associação de Plantas do Nordeste, 2005. p.101-133.

Gordin, C. R. B.; Scalon, S. P. Q; Masetto, T. E. Disponibilidade hídrica do substrato e teor de água da semente na germinação de niger. Pesquisa Agropecuária Tropical, v.45, p.312-318, 2015. http:// dx.doi.org/10.1590/1983-40632015v4535337

Jeller, H.; Perez, S. C. J. G. A.; Rauzer, J. Water uptake, priming, drying and storage effects in Cassia excelsa Schrad. seeds. Brazilian Journal of Biology, v.63, p.61-68, 2003. http://dx.doi.org/10.1590/ S1519-69842003000100008

Lacerda, A. V.; Barbosa, F. M.; E Barbosa, M. R. V. Estudo do componente arbustivo-arbóreo de matas ciliares da bacia do rio Taperoá, semiárido paraibano: Uma perspectiva para a sustentabilidade dos recursos naturais. Oecologia Brasiliensis, v.11, p.331-340, 2007.
Maguire, J. D. Speed of germination-aid in selection and evaluation for seedling emergence and vigor. Crop Science, v.2, p.176-177, 1962.

Marcos-Filho, J. Fisiologia de sementes de plantas cultivadas. 2.ed. Londrina: ABRATES, 2015. 660p.

Miranda, R. Q.; Correia, R. M.; Almeira-Cortez, J. S.; Pompelli, M. F. Germination of Prosopis juliflora (Sw.) D.C. seeds at different osmotic potentials and temperatures. Plant Species Biology, v.29, p.9-20, 2014. http://dx.doi.org/10.1111/1442-1984.12025

Nascimento, W. M. Condicionamento osmótico de sementes de hortaliças visando a germinação em condições de temperaturas baixas. Horticultura Brasileira, v.23, p.211-214, 2005. http://dx.doi. org/10.1590/S0102-05362005000200010

Pelegrini, L. L.; Borcioni, E.; Nogueira, A. C.; Koehler, H. S.; Quoirin, M. G. G. Efeito do estresse hídrico simulado com $\mathrm{NaCl}$, manitol e PEG (6000) na germinação de sementes de Erythrina falcata Benth. Ciência Florestal, v.23, p.511-519, 2013. http://dx.doi. org/10.5902/198050989295

Rabbani, A. R. C.; Mann, R. S.; Ferreira, R. A.; Pessoa, A. M. S.; Barros, E. S.; Mesquita, J. B. Restrição hídrica em sementes de moringa (Moringa oleifera L.). Revista Científica UDO Agrícola, v.12, p.201-207, 2012.

Rivera, R. M. F.; Sosa, L. R.; Fernández, E. A.; Reale, M. I.; Villarreal, V. Efecto del estrés hídrico a distintas temperaturas sobre la germinación de semillas de Bulnesia retama (Gill. ex. Hook.) Griseb. - Zigfiláceas - en San Luis, Argentina. International Journal of Experimental Botany, v.76, p.5-17, 2007.

Sampaio, E.; Gasson, P.; Baracat, A.; Cutler, D.; Pareyn, F.; Lima, K. C. Tree biomass estimation in regenerating areas of tropical dry vegetation in northeast Brazil. Forest Ecology and Management, v.259, p.11351140. 2010. http://dx.doi.org/10.1016/j.foreco.2009.12.028

Santos, A. R.; Silva-Mann, R.; Ferrera; R. A.; Brito, A. S. Water prehydration as priming for Moringa oleifera Lam. seeds under salt stress. Tropical and Subtropical Agroecosystems, v.14, p.201-207, 2011.

Stefanello, R. Garcia, D. C.; Menezes, N. L.; Muniz, M. F. B.; Wrasse, C. F. Efeito da luz, temperatura e estresse hídrico no potencial fisiológico de sementes de funcho. Revista Brasileira de Sementes, v.28, p.135141, 2006. http://dx.doi.org/10.1590/S0101-31222006000200018

Verslues, P. E.; Agarwal, M.; Katiyar-Agarwal, S.; Zhu, J.; Zhu, J. K. Methods and concepts in quantifying resistance to drought, salt and freezing, abiotic stress that affect plant water status. The Plant Journal, v.45, p.523-539, 2006. http://dx.doi.org/10.1111/j.1365313X.2005.02593.X

Villela, F. A.; Doni Filho, L.; Sequeira, E. L. Tabela de potencial osmótico em função da concentração de polietileno glicol 6000 e da temperatura. Pesquisa Agropecuária Brasileira, v.26, p.19571968, 1991. 